\title{
Environmental Impact from Lead-Zinc Mining and Lead-Arsenic Toxicity Effects in Arufu Area, Ne Nigeria.
}

\author{
Ekeleme, I. A. ${ }^{1}$, Olorunyomi, A. E. ${ }^{2}$ and Uzoegbu, M. U. ${ }^{3}$ \\ Petroleum Trust and Development Fund, Chair, Department of Geology and Mining, University of Jos, PMB \\ 2084, Jos, Nigeria. \\ Petroleum Trust and Development Fund, Chair, Department of Geology and Mining, University of Jos, PMB \\ 2084, Jos, Nigeria. \\ Geology Programme, Abubakar Tafawa Balewa University, P. M. B 0248, Bauchi, Nigeria.
}

\begin{abstract}
The six Upper Cretaceous lithogenic formations that formed the stratigraphic succession in the Arufu area are made up of Albian Arufu, Uomba and Gboko Formations i.e the Asu River Group. This is overlain by the Cenomanian -Turonian Keana and Awe Formations and the Cenomanain-Turonian Ezeaku Formation. The Ezeaku Formation is conterminous with the Konshisha River Group and the Wadata Limestone in the Makurdi area. The aim of this investigation is to reveal the impact of lead-zinc mining and highlight the effects of lead-arsenic to human health. Fifty soil and stream samples were analyzed using the Inductively Coupled Plasma - Optical Emission Spectroscopy (ICP-OES) technique. The values for the concentrations of the three elements ranges from; $A s(0-97.19 \mathrm{ppm}), C d(0-4.653 \mathrm{ppm}), \mathrm{Pb}(3.357$ - 59660ppm). Multiple correlation and regression analysis of the geochemical data showed a relationship between $\mathrm{Pb}$ and As and significant regression of $\mathrm{Pb}$ on $\mathrm{As}$ and $\mathrm{Cd}$. Results of the Index of geoaccumulation (Igeo), Contamination Factor (CF) and Degree of Contamination (Cdeg) indicate moderate to high $\mathrm{Pb}$ and As contamination. The values obtained indicates $\mathrm{As}, \mathrm{Pb}$ and $\mathrm{Cd}$ have concentrations above maximum permitted levels of 0.01ppm, 0.01ppm and 0.003 ppm respectively in water for human consumption, and above the threshold of contamination of 15ppm and 20ppm for As and Pb respectively. This suggests that more people will be at risk of pollutants as lead-zinc exploitation proceeds. Lead and arsenic values 15ppm and 20ppm were found exceeded the threshold 0.01ppm, $0.01 \mathrm{ppm}$ and 0.003ppm set by Standard Organization of Nigeria which is potentially highly toxic to biological systems and in water for human consumption. Fresh and old mining sites across the area should be revisited with the aim of assessing the level of environmental risk they pose to the health of the people in those communities and putting up measures to contain it.
\end{abstract}

Keywords: Cretaceous, mining, lead-arsenic, contamination, concentration, toxic.

\section{Introduction}

The studied area is characterized by low-lying topography with an average height of about $152 \mathrm{~m}$ above the sea level. The major river flowing through the area is the River Benue with its tributaries extending across the area. The pattern of drainage within the area covered is dendritic. Due to alternating periods of rainfall and dry seasons, most of the streams are seasonal; they overflow their banks during the raining season and become dried during long dry season. The main tributary that drains the area is River Uchembe. The tributaries of this river run in the southeast direction and are structurally controlled. The dominant rock type around Arufu are sedimentary rocks of the Asu River Group formation with a few indications of the Keana Formation characterized by coarse-grained sandstone and bands of shale in the area east of Arufu. Further down in the southern and south-eastern parts of the area reveals more exposures of gneisses. However, extensive superficial cover and poor exposures of the carbonate rocks made it difficult to establish the contact relationship pattern between the basement rocks and the Asu River Group.

Offodile (1976) work in the Upper, Middle and Lower Benue Trough reported that the area consists of sediments of the Cretaceous age $(136 \pm 25 \mathrm{Ma})$ and surrounded by the Pan African Precambrian Basement Complex $(600 \pm 150 \mathrm{Ma})$. He also observed that the region has three stratigraphical correlations; an upper or northeastern region; middle Benue region or the Lafia-Muri area and the lower or southwestern part of Makurdi (Fig. 2). He discussed the stratigraphic sequence of the Middle Benue trough under two sections of the Cretaceous Age.

i. Lower Cretaceous (which is represented by the Asu River Group and consists of dark shales, siltstones and fine grained sandstones) passing upwards into shales and limestones of the Upper Albian substage. 


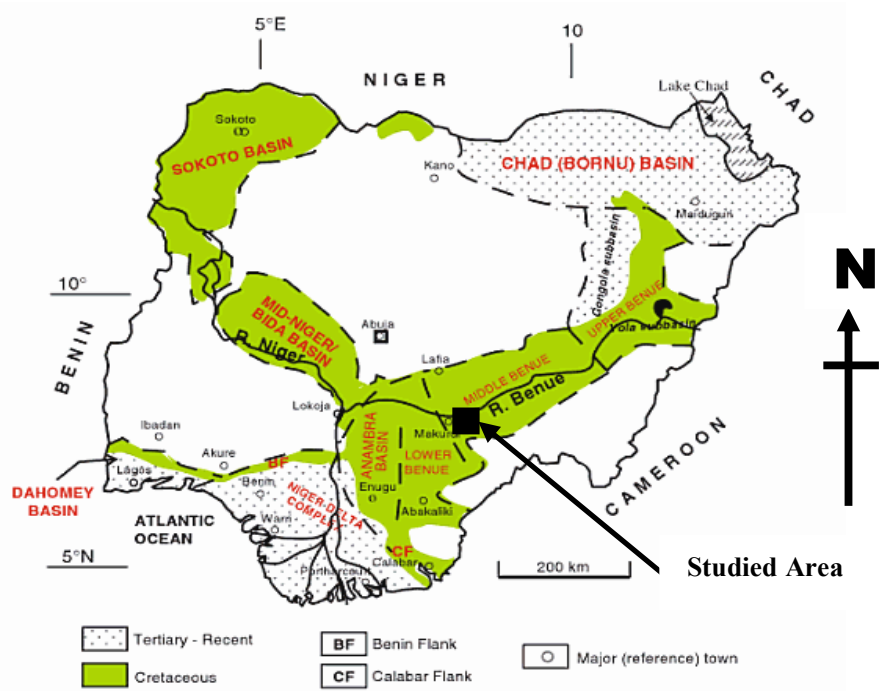

Fig. 1: Geological map of Nigeria showing the studied location (modified from Obaje, 2009)

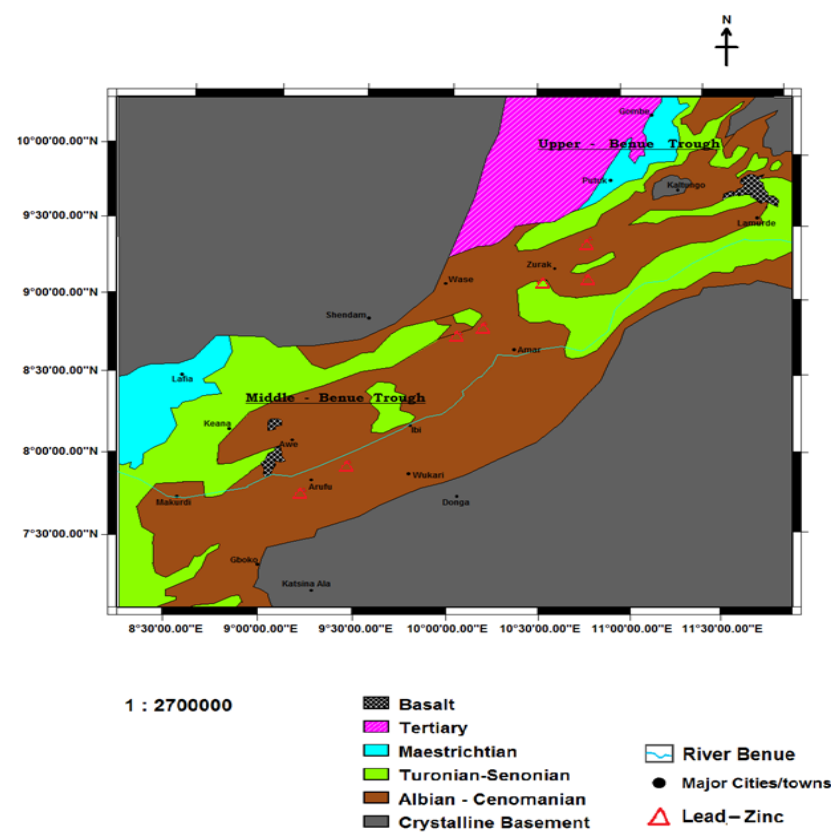

Fig. 2: Geological map of the Benue Trough, showing the units of the Middle Benue and Upper Benue subdivisions and lead-zinc occurrences. (modified from Cratchley and Jones, 1965 \& Whiteman, 1982).

ii Upper Cretaceous; which shows that the Asu River Group is immediately overlain by the Keana Sandstones which consists mainly of poorly sorted felspathic, coarse grained, gritty, commonly arkosic, pebbly sandstones.

The Middle Benue valley is subdivided into two parts which are: An Upper or northern part, which covers Bashar, Amar, Muri and Zurak areas and a Lower or Southern part which covers Lafia, Keana, Awe and Arufu area (Cratchey and Jones, 1965). They suggested the stratigraphic sequence in the Middle Benue valley given in Fig. 3. 
Fig. 3: Stratigraphic Sequence in the Middle Benue valley (After Cratchley and Jones, 1965)

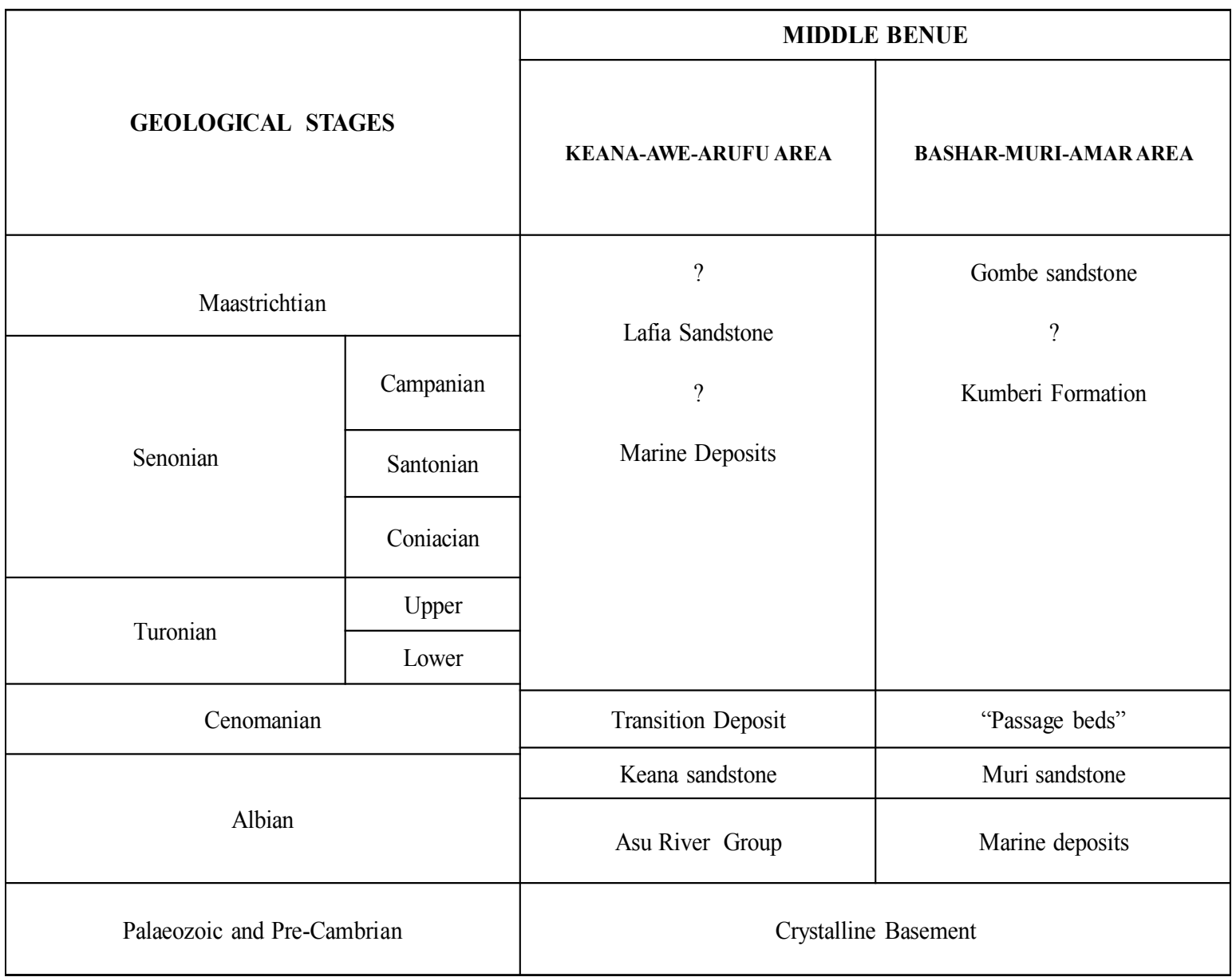

They also recognized a transitional zone (beds) overlying the Keana sandstone. These transitional beds are overlain by an unnamed marine formation consisting of shales, clays, siltstones and shelly limestones with some coals. Farrington (1952) described the lead-zinc mineralization of the Abakaliki fold belt pointing to its close association with the dioritic intrusive and albitized dolerites. He stated that the lead-zinc deposits are mainly fracture filling veins which form parts of fractured or sheeted zones. Farrington (1952) summarized ore genesis as follows for both Abakaliki and Benue areas:

i. Early intrusives are un-mineralized by sulphides (except for pyrite) but dolerites and porphyries are cut by ore bearing veins.

ii. Dolerites are albitized suggesting that emanations were active shortly after emplacement.

iii. Mineralization and intrusion both favour anticlinical structures.

iv. Dioritic intrusions are commonly associated with lead-zinc veins.

v. Mineralization west of Ishiagu is less than 4 miles from and at the same elevation as the base of mineralized and unintruded sediments of Coniacian age.

He believed in a magmatic hydrothermal origin but Whiteman (1982) suggests the more likely sources were hot brines which leached metals from sediments and Basement Complex. Some brine springs are known in the Abakaliki area and in the Benue Trough to the northeast. Whiteman (1982) suggests that the igneous bodies, because presumably they were warmer than the country rocks acted as sources of heat aiding movements of hot brine mineralizing fluids, and eventually became the loci for mineralization. Olade (1976) thinks that the ore solutions started as connate brines mobilized by geothermal heat from mantle plume activity during Cretaceous rifting. These solutions were able to leach chlorides from the sediments and evaporites, as well as base metals from clays and feldspars which combined with sulphur to form ores along permeable zones. Olade (1976) suggested also that the age of the mineralization is pre-Turonian. He thinks that the lead-zinc ores occur mainly in Albian sediments. Akande (1989) suggested a model which interpretes the Nigerian deposits in the Abakaliki, Ishiagu, Arufu-Akwana, Gombe and Zurak districts as distinct epigenetic ore bodies controlled by fractures which were formed about ninety (90) million years ago. The model suggests that the primary ore target should be the Asu River Group sediments in which the metal ore bodies are stratabound. Adikwu-Brown and Ogezi (1991) reported the adverse effects of lead mining in the Upper Benue Trough. They observed that lead mines 
pollute water sources in the area with cadmium. Lar and Sallau (2005) analyzed the trace elements in water and stream sediments from the Keana brines field, middle Benue Trough. They indicated that high concentrations of elements such as $\mathrm{As}, \mathrm{Pb}, \mathrm{Ni}$ and $\mathrm{Cr}$ were discovered in refined salt, while the concentration of $\mathrm{Cd}$ in well water was above WHO (World Health Organization) admissible limits. Ntekim (2008) carried out statistical analysis of trace elements concentrations in shale and carbonate sediments in Guyuk, North-eastern Nigeria. They observed that there are strong associations between trace elements such as $\mathrm{Cu}, \mathrm{Cr}, \mathrm{Ni}$ and $\mathrm{Co}$ and the process of mineralization in the area. They also observed that the trace elements have potential for use as mineralization indicators. This paper deals with determining the concentration of base metals $(\mathrm{Pb}, \mathrm{Ni}, \mathrm{Cu}$, ) in the soils and stream sediments within the locality, highlighting the possible toxicity effects on man, animals and crops of the area and to examine the mineralization potential of the area based on elemental analysis using ICP-OES.

\section{Regional Geologic Setting}

The Benue Trough of Nigeria is a rift basin in central West Africa that extends NNE - SSW for about $800 \mathrm{Km}$ in length and $150 \mathrm{Km}$ in width. The southern limit is the northern boundary of the Niger Delta, while the northern limit is the southern boundary of the Chad Basin (Fig. 4).

The trough contains up to $6000 \mathrm{~m}$ of Cretaceous - Tertiary sediments of which those predating the midSantonian have been compressionally folded, faulted, and uplifted in several places. Compressional folding during the mid-Santonian tectonic episode affected the whole of the Benue Trough and was quite intense, producing over 100 anticlines and synclines (Benkhelil, 1989). The Benue Trough is arbitrarily subdivided into a Lower, Middle and Upper portions (Fig. 1). No concrete line of subdivision can be drawn to demarcate the individual portions, but major localities (towns/settlements) that constitute the depocentres of the different portions have been well documented (Obaje, 2009). The depocentres of the Lower Benue Trough comprised mainly the areas around Nkalagu and Abakaliki, while those of the Anambra Basin centre are around Enugu, Awka and Okigwe. The Middle Benue Trough comprises the areas from Makurdi through Yandev, Lafia, Obi, Jangwa to Wukari. In the Upper Benue Trough, the depocentres comprise Pindiga, Gombe, Nafada, Ashaka (in the Gongola arm) and Bambam, Tula, Jessu, Dukul, Numanha (in the Yola arm), (Obaje, 2009).

In the Middle Benue Trough, around the Obi/Lafia area, six Upper Cretaceous lithogenic formations comprise the stratigraphic succession (Fig. 5). This succession is made up of Albian Arufu, Uomba and Gboko Formations, generally referred to as the Asu River Group (Offodile, 1976; Nwajide, 1990). These are overlain by the Cenomanian -Turonian Keana and Awe

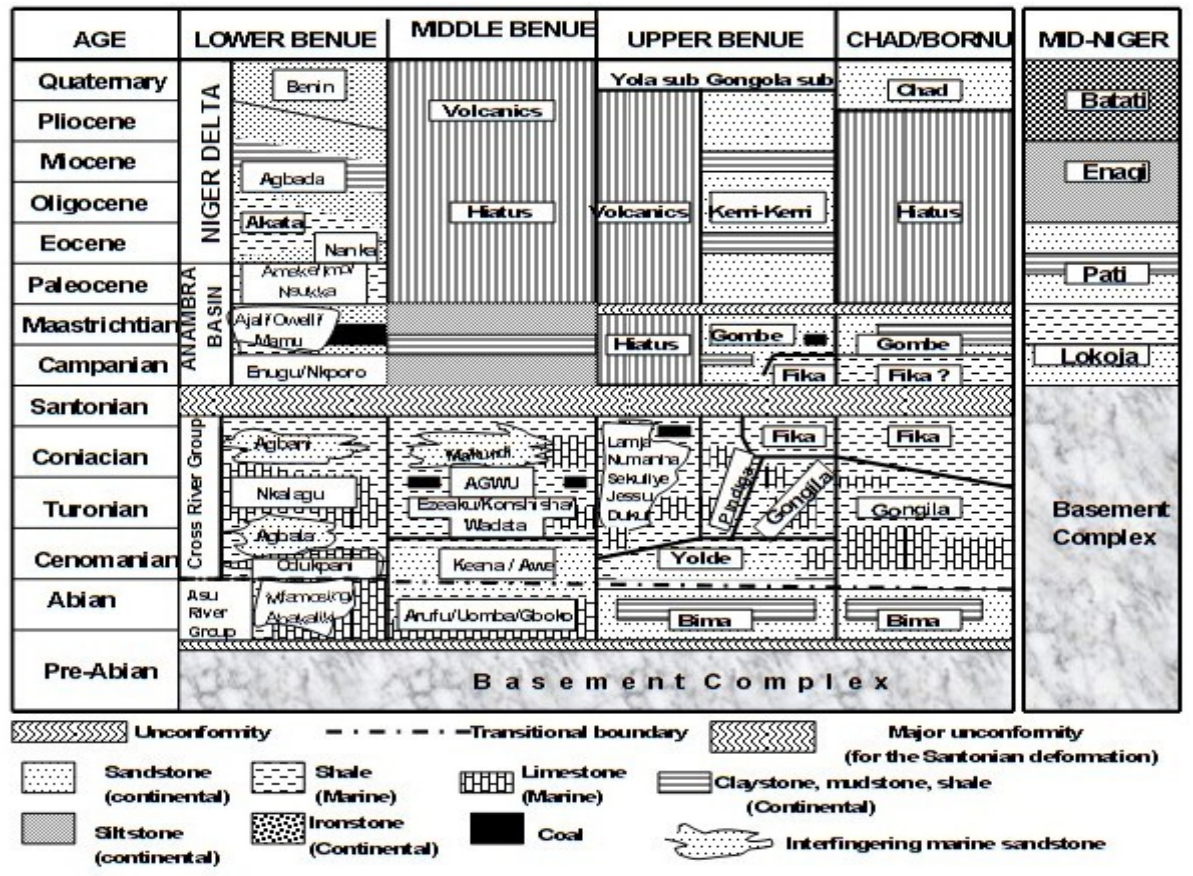

Fig. 4: Stratigraphic succession in the Be nue trough, the Nigerian sector of the Chad Basin, the Mid-Nige r Basin and relationship to the Niger delta (afte $r$ Obaje et al, 2006).

Formations and the Cenomanain -Turonian Ezeaku Formation. The Ezeaku Formation is coterminous with the Konshisha River Group and the Wadata Limestone in the Makurdi area. The Late Turonian-Early Santonian coal-bearing Awgu Formation lies conformably on the Ezeaku Formation. In the Makurdi area, the Makurdi 
Sandstone interfingers with the Awgu Formation. The mid-Santonain was a period of folding throughout the Benue Trough. The post-folding Campano-Maastrichtian Lafia Formation ended the sedimentation in the Middle Benue Trough, after which widespread volcanic activities took over in the Tertiary.

The Middle Benue Trough
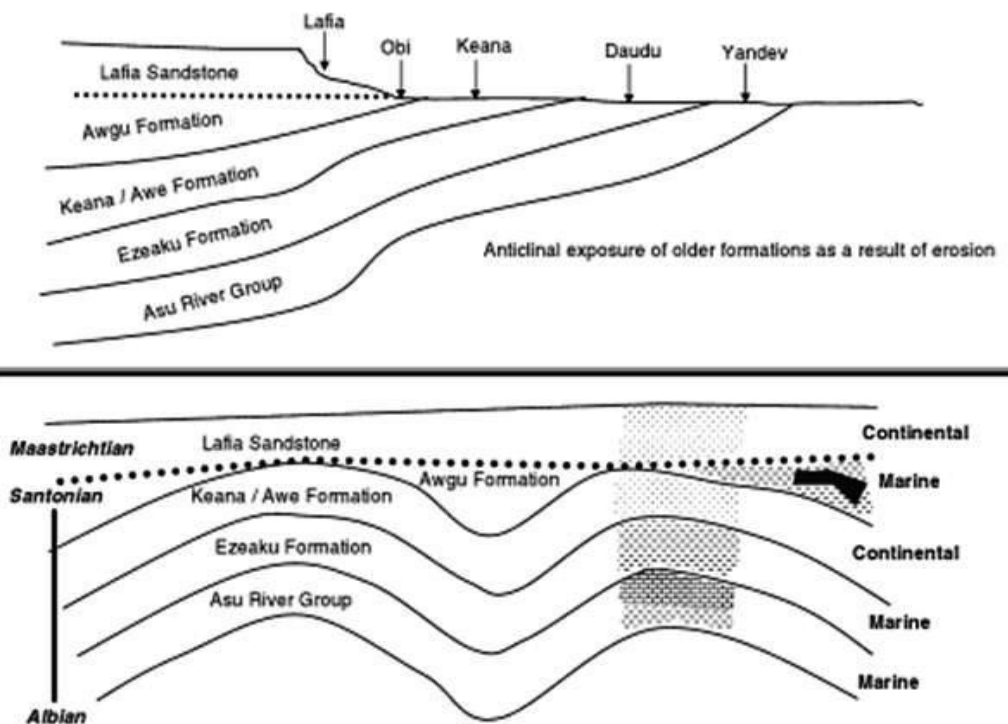

Fig. 5: Stratigraphic successions in the Middle Benue Trough (After Obaje, 2009)

The entire are zveals that the northern parts of Arufu have few outcrops of gneiss inliers which form a part of the Pan-Afric .... Jasement. The dominant rock types around Arufu are sedimentary

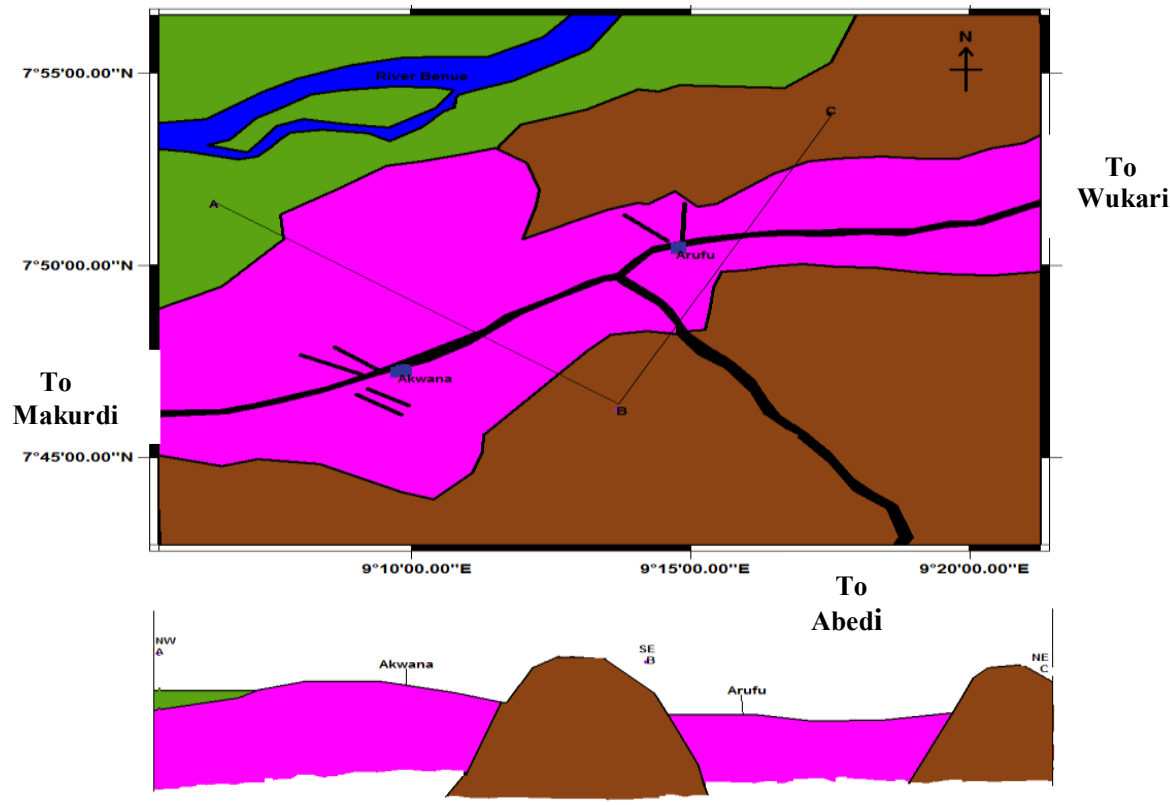

$1: 200000$

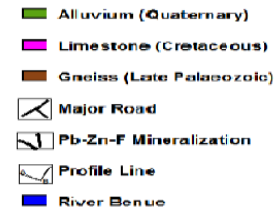

Fig. 6: Local geology in the Arufu and Akwana areas (After Akande, 1988) 
rocks of the Asu River Group formation with a few indications of the Keana Formation characterized by coarsegrained sandstone and bands of shale in the area east of Arufu. However, further down in the southern and south-eastern parts of the studied area reveals more exposures of Gneisses (Fig. 6). The purpose of this paper is to reveal the impact of lead-zinc mining and highlight the effects of lead-arsenic to human health.

\section{Materials And Methods}

The sampling intensity varied; at least three samples were obtained from most of the sample locations at intervals of $2 \mathrm{~m}$ to $6 \mathrm{~m}$ and five samples around mineralized veins or mine sites at intervals of $50 \mathrm{~cm}, 1 \mathrm{~m}, 4 \mathrm{~m}$, $20 \mathrm{~m}$ and $75 \mathrm{~m}$ respectively. The stream sediment samples were taken at the base of dried stream and at about $30 \mathrm{~cm}$ to $50 \mathrm{~cm}$ from the edge of the streams.

Precautions were taken to minimize contamination of samples during collection, preparation and analysis. Photographs of features as well as structural measurements were taken and all the observations and data obtained were recorded. The structural elements measured are mineralized veins and joints in altered carbonates, foliations and quartz veins in the gneisses. The collected samples were dried in the oven easy disintegrated to allow for homogenization. The samples were disintegrated using mortar and pestle which were properly cleaned with distilled water, methylated spirits and tissue paper in between each sample to prevent contamination. The fine powdery products were packed in labelled air-tight sample bags for easy identification. The collected and prepared samples were forwarded to the Geochemistry Laboratory of the Department of Geology and Mining, University of Jos for analyses. A total of 50 soil samples were analyzed for Lead, Arsenic and Cadmium using the ICP-OES machine. The disintegrated samples were decomposed using aqua regia. The conventional aqua regia digestion procedure consists of digesting soil samples on a hotplate with a 3:1 mixture of $\mathrm{HCl}$ and $\mathrm{HNO}_{3}$. The nitric acid reacts with concentrated $\mathrm{HCl}$ to form aqua regia (nitrosyl chloride and chlorine): $\mathrm{HNO}_{3}(a q)+3 \mathrm{HCl}(a q) \rightarrow \mathrm{NOCl}(g)+\mathrm{Cl}_{2}(g)+2 \mathrm{H}_{2} \mathrm{O}(l)$. The digested samples were then analyzed using the Inductively Coupled Plasma - Optical Emission Spectroscopy (ICP-OES) machine. With the ICP-OES multi-element capabilities were detected.

\section{Results And Discussion}

A total of 50 soil samples analyzed for the three elements (Table 1). The concentrations for the selected elements ranges with $\mathrm{As}(0-97.19 \mathrm{ppm}), \mathrm{Cd}(0-4.653 \mathrm{ppm}), \mathrm{Pb}(3.357-59660 \mathrm{ppm})$. The mean values are $9.072,0.227$ and 3656.7 respectively. The multiple correlation and regression values are used to show the relationships between concentrations of the different elements in the samples as well as detect the variation in their concentration with respect to that of lead $(\mathrm{Pb})$. Regression of lead against three elements arsenic and cadmium reveals significant regression of lead on arsenic and cadmium as 0.0000 and 0.0149 values respectively. Other elements show values higher than the acceptable 0.05 significant levels (Fig. 7). The correlation of lead against other elements is generally low with the exception of arsenic. This may indicate some sorts of geochemical restrictions on distribution and concentrations of the elements. It is also significant considering that the elements associated with lead - zinc mineralization are arsenic, silver, gold,

Table 1: Results of the Sample (A) and Statistical (B) data of 50 soil samples from the studied area

A

\begin{tabular}{|c|c|c|c|}
\hline Sampie Name & & & \\
& As (ppm) & Cd (ppm) & Pb (ppm) \\
\hline Ar1 (0.5m) & 0.0 & 0.0 & 802.8 \\
\hline Ar1 (3m) & 0.0 & 4.7 & 797.4 \\
\hline Ar1 (6m) & 15.9 & 1.7 & 1774.0 \\
\hline Ar2 (S3) & 0.0 & 1.4 & 274.4 \\
\hline Ar2 (S2) & 0.0 & 1.8 & 109.0 \\
\hline Ar3 & 0.0 & 0.0 & 124.2 \\
\hline Ar4 (S1) & 0.0 & 0.0 & 66.3 \\
\hline Ar4 (S3) & 18.9 & 0.0 & 57.6 \\
\hline Ar6 & 0.0 & 0.0 & 41.4 \\
\hline Ar8 (3m) & 74.7 & 0.0 & 47790.0 \\
\hline Ar8 (5m) & 70.1 & 0.2 & 59660.0 \\
\hline Ar8 (0.5m) & 62.2 & 0.6 & 44480.0 \\
\hline Ar9 & 1.7 & 0.0 & 79.2 \\
\hline Ar10 (1 m) & 0.0 & 0.0 & 256.6 \\
\hline
\end{tabular}

B

\begin{tabular}{|c|c|c|}
\hline $\mathbf{A s}$ & $\mathbf{C d}$ & $\mathbf{P b}$ \\
\hline 0.0 & 0.0 & 6.7 \\
\hline 0.0 & 1.7 & 6.7 \\
\hline 2.8 & 1.0 & 7.5 \\
\hline 0.0 & 0.9 & 5.6 \\
\hline 0.0 & 1.0 & 4.7 \\
\hline 0.0 & 0.0 & 4.8 \\
\hline 0.0 & 0.0 & 4.2 \\
\hline 3.0 & 0.0 & 4.1 \\
\hline 0.0 & 0.0 & 3.7 \\
\hline 4.3 & 0.0 & 10.8 \\
\hline 4.3 & 0.2 & 11.0 \\
\hline 4.1 & 0.5 & 10.7 \\
\hline 1.0 & 0.0 & 4.4 \\
\hline 0.0 & 0.0 & 5.6 \\
\hline
\end{tabular}




\begin{tabular}{|c|c|c|c|}
\hline $\operatorname{Ar} 10(4 m)$ & 0.0 & 0.0 & 150.1 \\
\hline $\operatorname{Ar10}(6 m)$ & 0.0 & 0.0 & 234.3 \\
\hline $\operatorname{Ar11}(\mathrm{S1})$ & 0.0 & 0.0 & 218.5 \\
\hline $\operatorname{Ar11}($ (S2) & 0.0 & 0.0 & 133.3 \\
\hline $\operatorname{Ar} 12(0.5 \mathrm{~m})$ & 0.0 & 0.0 & 359.9 \\
\hline $\operatorname{Ar} 12(2 m)$ & 0.0 & 0.0 & 290.7 \\
\hline $\operatorname{Ar} 12(5 m)$ & 22.8 & 0.0 & 227.5 \\
\hline $\operatorname{Ar} 13(0.5 m)$ & 97.2 & 0.0 & 19790.0 \\
\hline $\operatorname{Ar13}(5 m)$ & 29.0 & 0.0 & 3130.0 \\
\hline $\operatorname{Ar13}(10 m)$ & 0.0 & 0.0 & 120.6 \\
\hline $\operatorname{Ar} 14(5 m)$ & 14.0 & 0.0 & 94.2 \\
\hline $\operatorname{Ar} 14(10 m)$ & 0.0 & 0.0 & 15.6 \\
\hline $\operatorname{Ar} 14(0.5 m)$ & 0.0 & 0.0 & 30.7 \\
\hline Ar15 & 0.0 & 0.0 & 140.3 \\
\hline Ar16 & 0.0 & 0.0 & 77.1 \\
\hline Ay1 & 2.2 & 0.0 & 65.1 \\
\hline Ay2 & 0.0 & 0.0 & 38.4 \\
\hline Ay3 & 0.0 & 0.0 & 132.6 \\
\hline Ay4 (S1) & 0.0 & 0.0 & 94.9 \\
\hline Ay4 (S2) & 0.0 & 0.0 & 127.0 \\
\hline Ak1 (S1) & 0.0 & 0.1 & 87.8 \\
\hline Ak1 (S2) & 0.0 & 0.3 & 294.1 \\
\hline Ak2 & 0.0 & 0.0 & 70.9 \\
\hline Aj1 & 0.0 & 0.0 & 18.3 \\
\hline An1 & 0.0 & 0.0 & 31.4 \\
\hline An2 & 0.0 & 0.0 & 9.5 \\
\hline Gb1 (S1) & 8.1 & 0.3 & 36.6 \\
\hline Gb1 (S3) & 0.0 & 0.0 & 20.4 \\
\hline Ny1 (S1) & 0.0 & 0.1 & 3.4 \\
\hline Ny1 (S2) & 0.8 & 0.0 & 13.1 \\
\hline Sa1 (S3) & 7.3 & 0.0 & 74.6 \\
\hline Sa1 (S2) & 0.0 & 0.2 & 48.9 \\
\hline $\mathrm{Sa} 2$ & 28.8 & 0.0 & 59.5 \\
\hline Ty1 & 0.0 & 0.0 & 32.1 \\
\hline Ts2 & 0.0 & 0.0 & 129.7 \\
\hline
\end{tabular}

\begin{tabular}{|c|c|c|}
\hline 0.0 & 0.0 & 5.0 \\
\hline 0.0 & 0.0 & 5.5 \\
\hline 0.0 & 0.0 & 5.4 \\
\hline 0.0 & 0.0 & 4.9 \\
\hline 0.0 & 0.0 & 5.9 \\
\hline 0.0 & 0.0 & 5.7 \\
\hline 3.2 & 0.0 & 5.4 \\
\hline 4.6 & 0.0 & 9.9 \\
\hline 3.4 & 0.0 & 8.0 \\
\hline 0.0 & 0.0 & 4.8 \\
\hline 2.7 & 0.0 & 4.6 \\
\hline 0.0 & 0.0 & 2.8 \\
\hline 0.0 & 0.0 & 3.5 \\
\hline 0.0 & 0.0 & 5.0 \\
\hline 0.0 & 0.0 & 4.4 \\
\hline 1.2 & $\overline{0.0}$ & 4.2 \\
\hline 0.0 & 0.0 & 3.7 \\
\hline 0.0 & 0.0 & 4.9 \\
\hline 0.0 & 0.0 & 4.6 \\
\hline 0.0 & 0.0 & 4.9 \\
\hline 0.0 & 0.1 & 4.5 \\
\hline 0.0 & 0.3 & 5.7 \\
\hline 0.0 & 0.0 & 4.3 \\
\hline 0.0 & 0.0 & 3.0 \\
\hline 0.0 & 0.0 & 3.5 \\
\hline 0.0 & 0.0 & 2.4 \\
\hline 2.2 & 0.3 & 3.6 \\
\hline 0.0 & 0.0 & 3.1 \\
\hline 0.0 & 0.1 & 1.5 \\
\hline 0.6 & 0.0 & 2.6 \\
\hline 2.1 & 0.0 & 4.3 \\
\hline 0.0 & 0.2 & 3.9 \\
\hline 3.4 & 0.0 & 4.1 \\
\hline 0.0 & 0.0 & 3.5 \\
\hline 0.0 & 0.0 & 4.9 \\
\hline 0.0 & 0.0 & 4.8 \\
\hline
\end{tabular}

iron, copper, antimony and selenium in sulphide and base-metal deposits (Fig. 7). A significant correlation exists between cobalt, chromium, copper and nickel. The frequency distribution plots of the elements except lead generally show unimodal distribution indicating that most of the elements belong to a common parent material (Fig. 8).

The plots are generally skewed right and indicated only a few outliers not belonging to the population. The calculated Igeo values of the elements in samples are $\mathrm{As}$ (5.43), $\mathrm{Cd}$ (1.63) and $\mathrm{Pb}$ (7.64) Table 2. The mean values of Igeo decrease in the order $\mathrm{As}>\mathrm{Pb}>\mathrm{Cd}>(2.74,-1.00,-1.92)$ indicating that arsenic and lead have 
significant concentrations. This is buttressed by the Contamination Factor (CF) which shows mean values decrease in the order $\mathrm{Pb}>\mathrm{As}>\mathrm{Cd}(298,65,5)$ Table 2. The mean values also decreases in the same order as $18.29>6.05>0.15$. The degree of contamination (Cdeg) ranges from 0.086 to 345.7 with mean value of 26.16 indicating a low to moderate degree of contamination. However, high degree of contamination is observed in the immediate vicinity of the Arufu village with peak values greater than $200 \mathrm{Cdeg}$.

Statistical analyses which involve histogram and cumulative frequency plots, correlation and regression analysis were carried out on the result obtained from the laboratory. Furthermore, quantification of contamination indices such as contamination factor (CF) and Index of geoaccumulation (Igeo) were used to determine the relationships in the concentrations and distribution patterns of the elements analyzed which will help in the interpretation of results obtained.

Statistical analyses which involve histogram and cumulative frequency plots and regression analysis were carried out (Table 1). Further quantification of contamination indices such as contamination factor (CF) and Index of geoaccumulation (Igeo) were also undertaken (Table 2). The aim was to see if there are relationships in the concentrations and distribution patterns of the elements analyzed which will help to adequately interpret the result.

Table 2: Results of the Index of geoaccumulation (IGEO), Contamination Factor (CF) and Contamination Degree (Cdeg).

\begin{tabular}{|c|c|c|c|c|c|c|c|}
\hline & Igeo & & $\mathrm{C}$ & & & & $\mathbf{C}_{\operatorname{deg}}$ \\
\hline $\begin{array}{c}\text { Sample } \\
\text { Location }\end{array}$ & As & Cd & $\mathbf{P b}$ & As & Cd & $\mathbf{P b}$ & \\
\hline Ar1 (0.5m) & - & - & 1.4 & 0.0 & 0.0 & 4.0 & 4.0 \\
\hline Ar1 (3m) & - & 1.6 & 1.4 & 0.0 & 4.7 & 4.0 & 8.7 \\
\hline Ar1 (6m) & 2.8 & 0.2 & 2.6 & 10.6 & 1.7 & 8.9 & 21.2 \\
\hline Ar2 (S3) & - & -0.1 & -0.1 & 0.0 & 1.4 & 1.4 & 2.8 \\
\hline Ar2 (S2) & - & 0.2 & -1.5 & 0.0 & 1.8 & 0.5 & 2.4 \\
\hline Ar3 & - & - & -1.3 & 0.0 & 0.0 & 0.6 & 0.6 \\
\hline Ar4 (S1) & - & - & -2.2 & 0.0 & 0.0 & 0.3 & 0.3 \\
\hline Ar4 (S3) & 3.1 & - & -2.4 & 12.6 & 0.0 & 0.3 & 12.9 \\
\hline Ar6 & - & - & -2.9 & 0.0 & 0.0 & 0.2 & 0.2 \\
\hline Ar8 (3m) & 5.1 & - & 7.3 & 49.8 & 0.0 & 239.0 & 288.8 \\
\hline Ar8 (5m) & 5.0 & -2.6 & 7.6 & 46.7 & 0.2 & 298.3 & 345.2 \\
\hline $\operatorname{Ar8}(0.5 m)$ & 4.8 & -1.4 & 7.2 & 41.4 & 0.6 & 222.4 & 264.4 \\
\hline Ar9 & -0.4 & - & -1.9 & 1.1 & 0.0 & 0.4 & 1.5 \\
\hline $\operatorname{Ar10}(1 \mathrm{~m})$ & - & - & -0.2 & 0.0 & 0.0 & 1.3 & 1.3 \\
\hline $\operatorname{Ar} 10(4 m)$ & - & - & -1.0 & 0.0 & 0.0 & 0.8 & 0.8 \\
\hline $\operatorname{Ar10}(6 \mathrm{~m})$ & - & - & -0.4 & 0.0 & 0.0 & 1.2 & 1.2 \\
\hline Ar11 (S1) & - & - & -0.5 & 0.0 & 0.0 & 1.1 & 1.1 \\
\hline Ar11 (S2) & - & - & -1.2 & 0.0 & 0.0 & 0.7 & 1.1 \\
\hline $\operatorname{Ar} 12(0.5 m)$ & - & - & 0.3 & 0.0 & 0.0 & 1.8 & 1.8 \\
\hline $\operatorname{Ar} 12(2 m)$ & - & - & 0.0 & 0.0 & 0.0 & 1.5 & 1.5 \\
\hline $\operatorname{Ar} 12(5 \mathrm{~m})$ & 3.3 & - & -0.4 & 15.2 & 0.0 & 1.1 & 16.3 \\
\hline $\operatorname{Ar} 13(0.5 m)$ & 5.4 & - & 6.0 & 64.8 & 0.0 & 99.0 & 163.8 \\
\hline $\operatorname{Ar} 13$ (5m) & 3.7 & - & 3.4 & 19.4 & 0.0 & 15.7 & 35.1 \\
\hline $\operatorname{Ar} 13(10 m)$ & - & - & -1.3 & 0.0 & $\mathbf{0 . 0}$ & 0.6 & 0.6 \\
\hline $\operatorname{Ar} 14(5 m)$ & 2.6 & - & -1.7 & 9.4 & 0.0 & 0.5 & 9.9 \\
\hline $\operatorname{Ar} 14(10 m)$ & - & - & -4.3 & 0.0 & 0.0 & 0.1 & 0.1 \\
\hline $\operatorname{Ar14}(0.5 \mathrm{~m})$ & - & - & -3.3 & 0.0 & 0.0 & 0.2 & 0.2 \\
\hline Ar15 & - & - & -1.1 & 0.0 & 0.0 & 0.7 & 0.7 \\
\hline Ar16 & - & - & -2.0 & 0.0 & 0.0 & 0.4 & 0.4 \\
\hline Ay1 & 0.0 & - & -2.2 & 1.5 & 0.0 & 0.3 & 1.8 \\
\hline Ay2 & - & - & -3.0 & 0.0 & 0.0 & 0.2 & 0.2 \\
\hline Ay3 & - & - & -1.2 & 0.0 & 0.0 & 0.7 & 0.7 \\
\hline Ay4 (S1) & - & - & -1.7 & 0.0 & 0.0 & 0.5 & 0.5 \\
\hline Ay4 (S2) & - & - & -1.2 & 0.0 & 0.0 & 0.6 & 0.6 \\
\hline Ak1 (S1) & - & -4.2 & -1.8 & 0.0 & 0.1 & 0.4 & 0.5 \\
\hline Ak1 (S2) & - & -2.4 & 0.0 & 0.0 & 0.3 & 1.5 & 1.8 \\
\hline Ak2 & - & - & -2.1 & 0.0 & 0.0 & 0.4 & 0.4 \\
\hline
\end{tabular}


Environmental Impact From Lead-Zinc Mining And Lead-Arsenic Toxicity Effects In Arufu Area, Ne

\begin{tabular}{|c|c|c|c|c|c|c|c|c|} 
Aj1 & - & - & -4.0 & & 0.0 & 0.0 & 0.1 & 0.1 \\
\hline An1 & - & - & -3.3 & & 0.0 & 0.0 & 0.2 & 0.2 \\
\hline An2 & - & - & -5.0 & & 0.0 & 0.0 & 0.0 & 0.0 \\
\hline Gb1 (S1) & 1.8 & -2.2 & -3.0 & & 5.4 & 0.3 & 0.2 & 5.9 \\
\hline Gb1 (S3) & - & -5.1 & -3.9 & & 0.0 & 0.0 & 0.1 & 0.1 \\
\hline Ny1 (S1) & - & -4.6 & -6.5 & & 0.0 & 0.1 & 0.0 & 0.1 \\
\hline Ny1 (S2) & -1.5 & - & -4.5 & & 0.5 & 0.0 & 0.1 & 0.6 \\
\hline Sa1 (S3) & 1.7 & - & -2.0 & & 4.9 & 0.0 & 0.4 & 5.3 \\
\hline Sa1 (S2) & - & -2.6 & -2.6 & & 0.0 & 0.2 & 0.2 & 0.4 \\
\hline Sa2 & 3.7 & - & -2.3 & & 19.2 & 0.0 & 0.3 & 19.5 \\
\hline Ty1 & - & - & -3.2 & & 0.0 & 0.0 & 0.2 & 0.2 \\
\hline Ts2 & - & - & -1.2 & & 0.0 & 0.0 & 0.6 & 0.6 \\
\hline Ts1 & - & - & -1.3 & & 0.0 & 0.0 & 0.6 & 0.6 \\
\hline
\end{tabular}

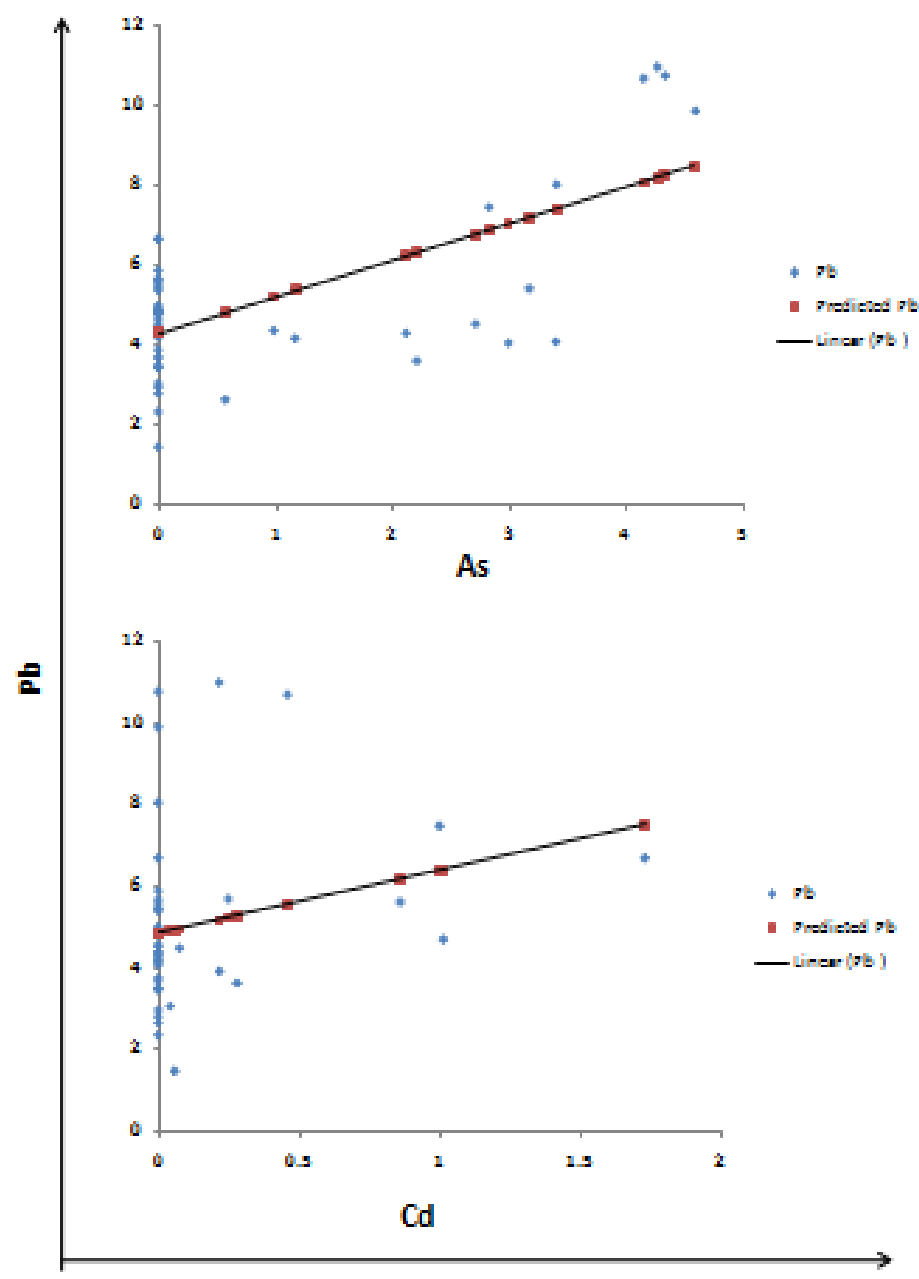

Fig. 7: Chart reflecting the result of Regression analysis indicating the relationship between $\mathrm{As}, \mathrm{Cd}$ and $\mathrm{Pb}$ across the area. 


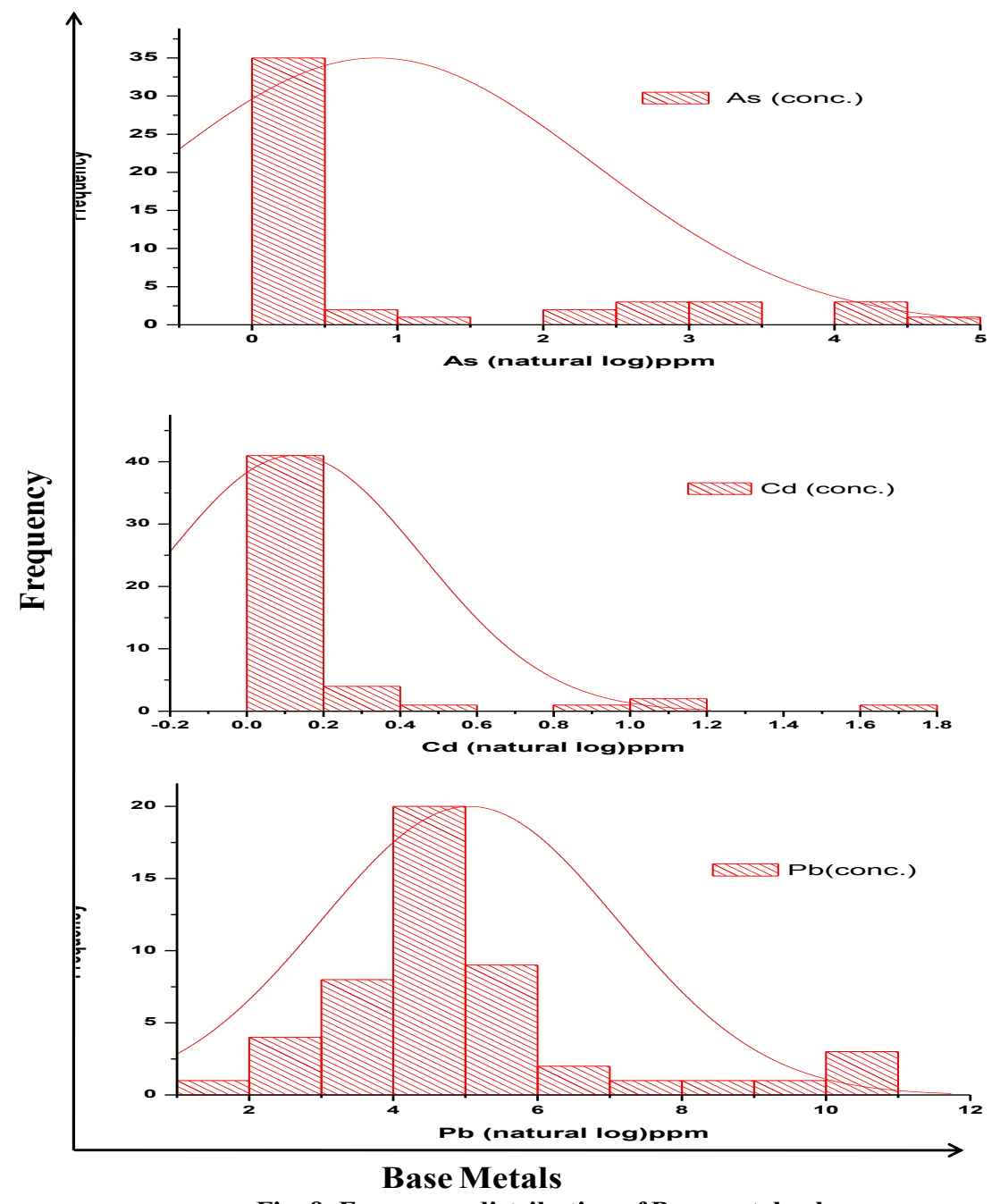

Fig. 8: Frequency distribution of Base metal values

Geochemical maps for the area are presented below in form of contours. The purpose is to indicate the distribution and concentrations of each of the elements analyzed in the area.

\section{Arsenic}

Arsenic concentrations within the studied area (Table 1) range from 0 to $97.19 \mathrm{ppm}$ with a mean value of 9.072ppm. Forty (40) of the samples (representing $80 \%$ ) have values within the range of 0 and $10 \mathrm{ppm}$. Samples with greater than average arsenic content were those around mine pits.

There was a positive correlation between the concentration of Arsenic and Lead. The bivariate scatter plot (Fig. 7) also predicts that with increasing concentration of arsenic in the study area, more lead will be discovered. The geochemical map indicates the distribution and concentration of arsenic the studied area (Fig. 9). The value of the Igeo 5.43 (Table 2) showed moderate to high contaminations of arsenic in soils around areas where active mining is going on or have been done over the years. This is also supported by the result obtained from the calculation of the contamination factor 6.05 (Table 2) which shows very high contamination factor (Fig. 10). Most environmental arsenic problems are the result of mobilization under natural conditions. However, man through mining activity has added more arsenic problem to the area. Mining-related arsenic problems in water and the environment have been identified in many parts of the world, including Ghana, Greece, Thailand and the USA (Smedley and Kinniburgh, 2002). Arsenic occurs as a major constituent in more than 200 minerals, including elemental arsenic, arsenides, sulphides and oxides. The greatest concentrations of these minerals occur in mineralized areas. As the chemistry of arsenic follows closely that of sulphur, the greatest concentrations of the element tend to occur in sulphide minerals of which pyrite is the most abundant (Smedley and Kinniburgh, 2002). Arsenic is present in the crystal structure of many sulphide minerals as a substitute for Sulphur. Arsenic can also substitute for $\mathrm{Si}^{4+}, \mathrm{Al}^{3+}, \mathrm{Fe}^{3+}$ and $\mathrm{Ti}^{4+}$ in many mineral structures and is present in other rock-forming minerals at much lower concentrations. Carbonate minerals usually contain less 
than 10ppm arsenic. Arsenic concentrations in igneous rocks are generally low. Ure and Berrow (1982) quoted an average value of $1.5 \mathrm{ppm}$ for all igneous rock types (undistinguished). Arsenic concentrations in metamorphic rocks tend to reflect the concentrations in their igneous and sedimentary precursors. Most contain around 5ppm or less. Pelitic rocks (slates, phyllites) typically have the highest concentrations with an average value of $18 \mathrm{ppm}$. The concentration of arsenic in sedimentary rocks is typically in the range 5-10 ppm (Wester, 1999). The background level in top-soils is typically low, but generally higher than that of the parent material (Norrish, 1975) and occasionally exceeds the threshold of contamination of $15 \mathrm{ppm}$ as given by the NRCC (National Research Council of Canada) (NRCC, 1978b). Arsenic minerals and compounds are soluble, but there is limited movement of arsenic in soil because it is absorbed by hydroxides, clays and organic matter (Kabata-Pendias and Pendias, 1992), and retained by iron oxides (Norrish, 1975). Therefore, its mobility is highest in sandy soils and lowest in fine textured soils and those high in iron (NRCC, 1978)

Arsenic concentrations much higher than baseline values have been found in sediments and soils contaminated by the products of mining activity, including mine tailings and effluent. Concentrations in tailings piles and tailings-contaminated soils can reach up to several thousand ppm. Humans can be exposed to arsenic through ingestion of arsenic-containing water, food, and drugs (such as Fowler's solution containing 1\% of potassium arsenite used to treat psoriasis and arsenic trioxide used to treat leukemia). Airborne arsenic can be absorbed into the bloodstream in workers involved in the processing of copper, gold, and lead ores; in the production and use of arsenic-containing pesticides. Water contamination is the most common source of arsenic exposure (Weinstein, 1997). Of concern today are the skin lesions and cancers observed
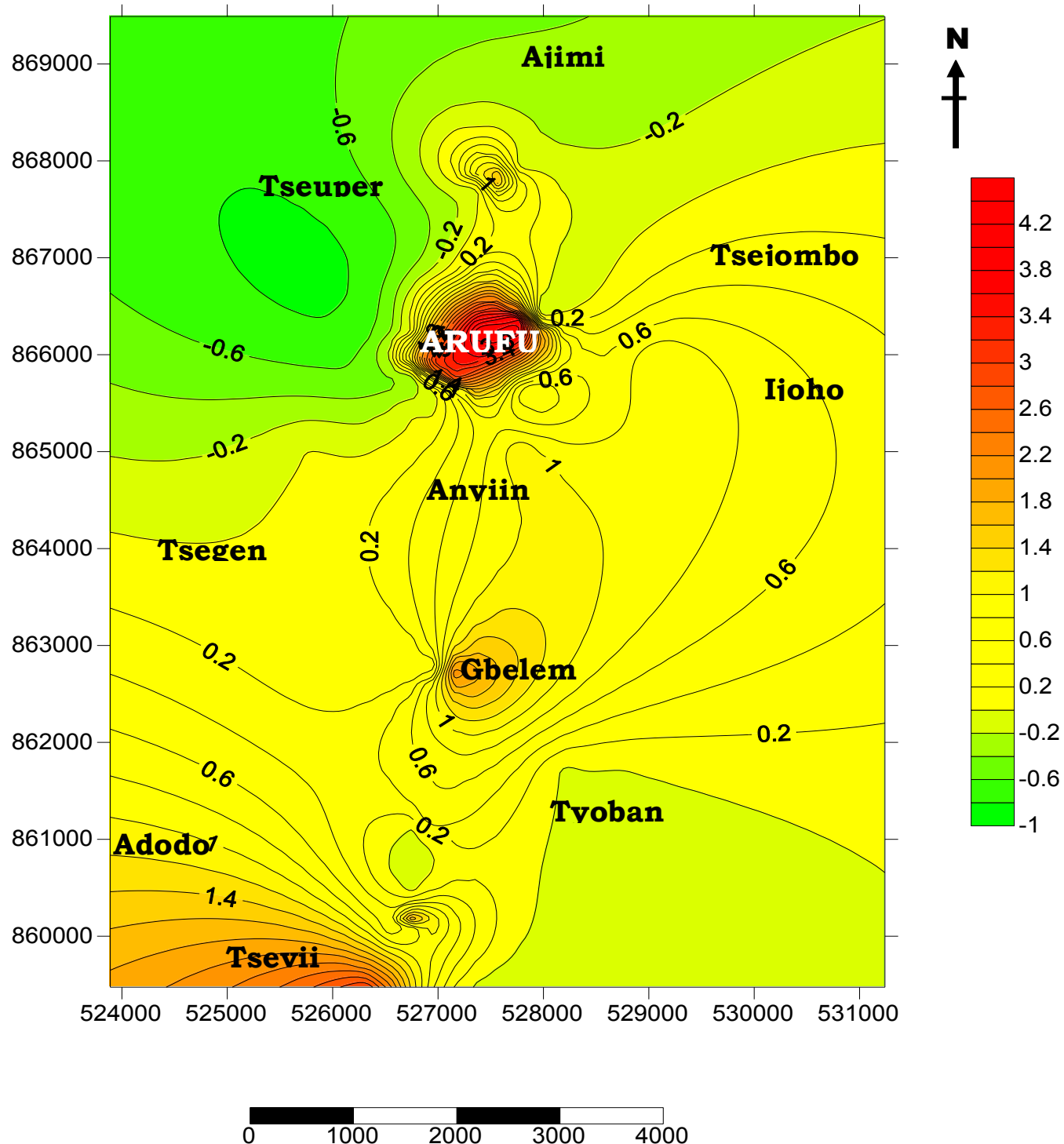

Fig. 9: The distribution and concentration of Arsenic distribution in the area. 

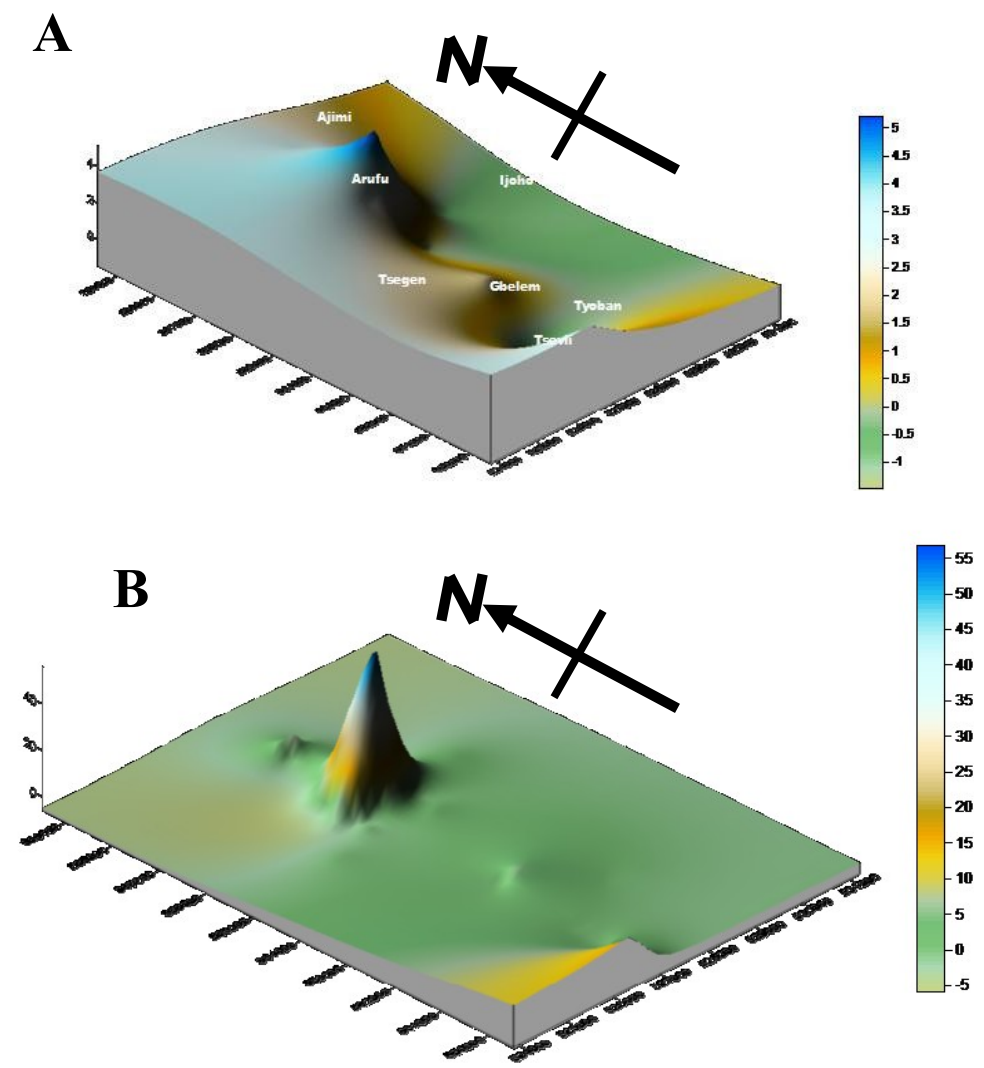

Fig. 10: The Arsenic contamination map for (a) IGEO and (b) CF values

among the millions of people drinking arsenic-rich well water, especially in West Bengal and Bangladesh. Chronic arsenic poisoning may affect many organ systems. For example, in affected

populations in Taiwan and India, ingestion of drinking water high in arsenic has been associated with a variety of skin lesions, which include increased or decreased pigmentation and keratosis. Gangrene has also been reported (blackfoot disease). The carcinogenic role of arsenic has been suggested in a range of studies: exposure increases the risk of cancer of the skin, lung, liver, bladder, and kidneys (Weinstein, 1997). In recent years, long-term exposure to arsenic from drinking water has also been found to be highly associated with hypertension and diabetes mellitus (Tseng, 1999). The maximum permitted concentration of arsenic in drinking water is $0.01 \mathrm{mg} / \mathrm{L} \quad(\approx 0.01 \mathrm{ppm})$. Arsenic is not a requirement for animals or humans. It can be toxic to plants in leaf concentrations of 5-20 ppm (dry weight basis) with symptoms including wilting, reduced growth and root discolouration (Kabata-Pendias and Pendias, 1992). It is unlikely that phytotoxic arsenic levels will result in the poisoning of consumers because plants will cease to grow if roots have absorbed too much arsenic, and fruits and seeds will not have elevated levels (NRCC, 1978).

\section{Cadmium}

Cadmium concentrations within the study area (Table 1) range from 0 to $4.653 \mathrm{ppm}$ with a mean value of $0.227 \mathrm{ppm}$. This is also reflected by the bivariate scatter plot (Fig. 7). The geochemical map indicates the distribution and concentration of cadmium the studied area (Fig.11). The value of the Igeo 1.63 (Table 2) showed that the soils have low to moderate levels of contamination. This is also supported by the result obtained from the calculation of the contamination factor 5.00 (Table 2) which indicated low to moderate contamination factor (Figs. 12). 


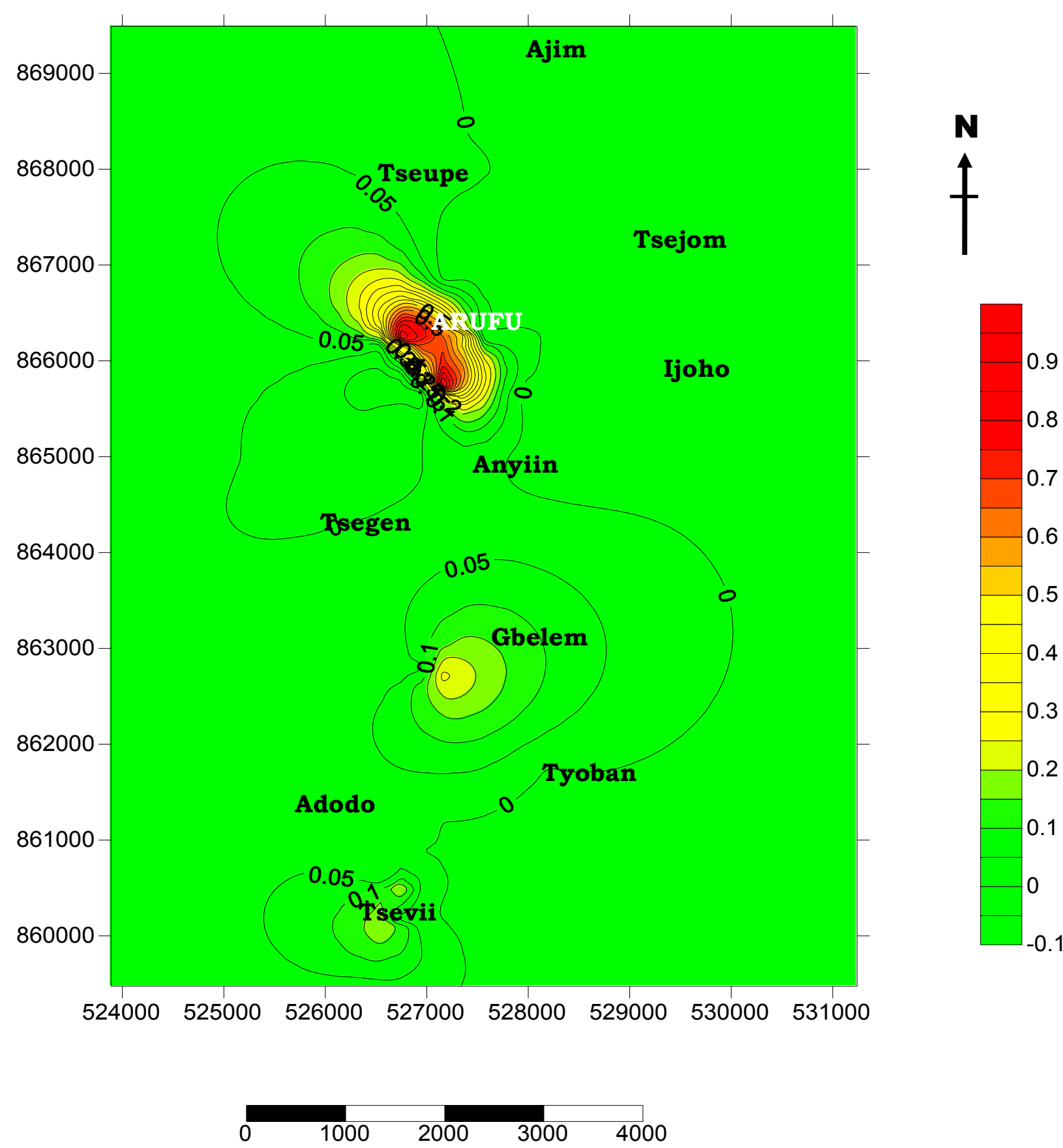

Fig. 11: The distribution and concentration of Cadmium distribution in the area. 
A

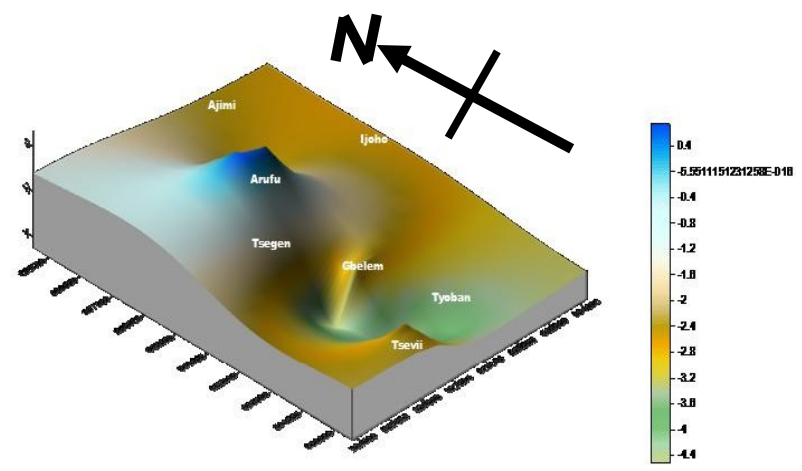

B

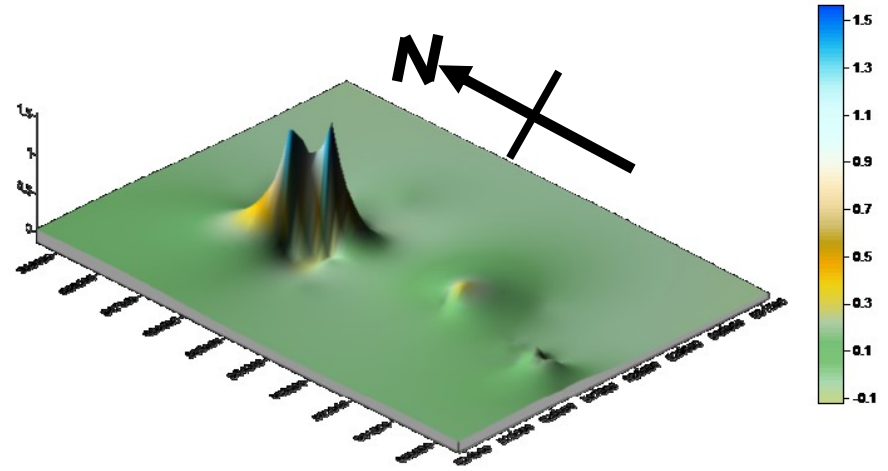

Fig. 12: The Cadmium contamination map for (a) IGEO and (b) CF values

The samples from locations Ar1 and Ar2 in particular, indicate moderate levels of contamination. This raises health concerns about the inhabitants of the area considering that the maximum level of Cadmium permitted in water for human consumption is $0.003 \mathrm{mg} / \mathrm{L}(\approx 0.003 \mathrm{ppm})$. Cadmium is present mainly in organic-rich shales $(0.22-0.30 \mathrm{ppm})$, and in igneous rocks. It is highest in mafic units (0.13-0.22 ppm) (Kabata-Pendias and Pendias, 1992). Cadmium can be found primarily in sulphide minerals such as sphalerite and pyrite. Upon weathering, these minerals will release $\mathrm{Cd}^{2+}$ into solution. It is in this form that Cadmium is taken up by plants, although content in solution will be low, as $\mathrm{Cd}^{2+}$ will form complex ions and organic chelates in soil. Its mobility will then be controlled primarily by $\mathrm{pH}$ and redox potential (Kabata-Pendias and Pendias, 1992). Cadmium is most mobile at $\mathrm{pH}$ 4.5-5.5 (Kabata-Pendias and Pendias, 1992). With no known biological functions, the main concern regarding cadmium is its role as a toxicant. It can rapidly accumulate in livestock and other animals, particularly in kidneys and other organs, creating a potential hazard for human consumption (CCREM, 1995). Cadmium is phytotoxic at leaf levels of 5- 30 ppm (Kabata-Pendias and Pendias, 1992) but it can accumulate within edible portions of the plant to sub-toxic levels without resulting in any plant distress (Alloway, 1990). Cadmium can be taken up by plants through leaves or roots but soluble soil Cd is readily available (Kabata-Pendias and Pendias, 1992) and it is thought that this is the main source of plant Cd (FAO, 1992). Actual phytotoxicity can occur on polluted soils, but it is rare (Alloway, 1990), and Cadmium is generally not harmful to plants (FAO, 1992). Accumulation of Cadmium in animals can cause disease if it replaces Zinc in enzymes; symptoms of toxicity include renal degradation, emphysema, intestinal dysfunctions and anaemia (Lagerwerff, 1972). Cadmium is known to be more toxic to an animal if dietary calcium is low (CCREM, 1995).

\section{Lead}

Lead concentrations within the study area (Table 1) range from 3.357 to 59660ppm with a mean value of $3656.7 \mathrm{ppm}$. Arsenic concentrations show a strong correlation with the concentrations of Lead. This is also indicated in the bivariate scatter plot (Fig. 7). The geochemical map indicates the distribution and concentration of cadmium the studied area (Fig. 13). The values of the Igeo 7.64 (Table 2) for samples around mining sites show a range from moderate to extreme lead contamination. This is corroborated by the result obtained from the calculation of the contamination factor 18.29 (Table 2) which shows moderate to very high contamination factor (Figs. 14). Those used as control samples obtained from other locations around shows they are largely uncontaminated.

Lead occurs as a sulphide in rocks and replaces $\mathrm{K}, \mathrm{Ba}, \mathrm{Sr}$ and $\mathrm{Ca}$ in minerals (Norrish, 1975). The largest presence of lead occurs in argillaceous sediments (20-40 ppm) and shales (18-25 ppm), but amounts are also high in felsic rocks (15-24 ppm). The overall range of lead in world soils is 3-189 ppm with a range in 
means of 10-67 ppm and an overall average level of $32 \mathrm{ppm}$ (Kabata-Pendias and Pendias, 1992). A threshold of contamination of $20 \mathrm{ppm}$ has been suggested based on the low lead levels found in Alaskan soils (range of means: 22-28 ppm) (Kabata- Pendias and Pendias, 1992).

Least mobile of the heavy metals, lead accumulates in the surface horizons of soils and is not usually leached (Davies, 1990). Its concentration in solution is low, and this limited amount is available for plant uptake (Davies, 1990). It exists in soil solution mainly as $\mathrm{Pb}^{2+}$, but it may also occur in the $\mathrm{Pb}^{4+}$ oxidation state. Soil is mainly associated with organic matter, clay minerals and oxides of Manganese, Iron and Aluminum (KabataPendias and Pendias, 1992). Lead is most
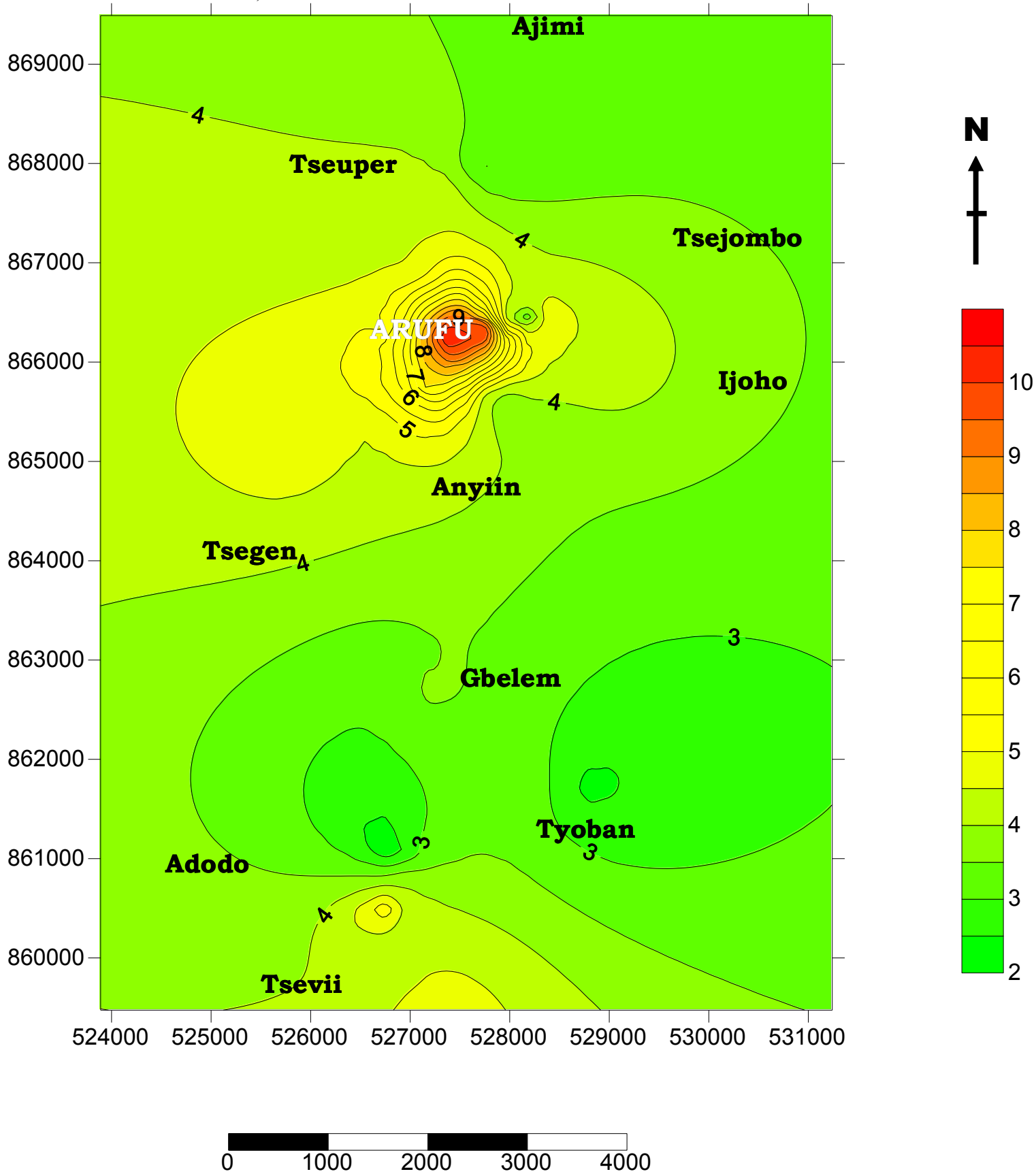

Fig. 13: The distribution and concentration of Lead distribution in the area.

available under acid conditions (particularly in sandy soil) (NRCC, 1978a) and precipitates as hydroxides, phosphates and carbonates as $\mathrm{pH}$ increases (Lagerwerff, 1972). In association with Manganese oxides, the solubility of lead decreases as $\mathrm{Pb}^{2+}$ is oxidized to $\mathrm{Pb}^{4+}$ (McBride, 1994).

Lead is a non essential element for plants, animals and humans. It is toxic to plants at leaf levels of 30$300 \mathrm{ppm}$ (dry weight basis), at which point plants exhibit dark green leaves, wilting, and stunted foliage and 
roots (Kabata-Pendias and Pendias, 1992). Although lead can be absorbed through roots and foliage (Lagerwerff, 1972) phytotoxicities are rarely observed under field conditions. Lead is highly toxic to animals at a level of 30ppm in diet on a dry weight basis (FAO, 1992) and leads to efficiency problems in red blood cell synthesis (NRCC, 1978a). Translocation of lead within plants is low (McBride, 1994; Kabata-Pendias and Pendias, 1992), so the main health concern for humans and animals is ingestion of soil with plants (McBride, 1994), although elevated Lead levels in root crops may be a problem. The guideline established for Lead in water for human consumption is $0.01 \mathrm{mg} / \mathrm{L}(\approx 0.01 \mathrm{ppm})$.

The wide range in concentration of total trace elements investigated in this area reflects the interaction of at least two factors:

i. $\quad$ The varied nature of the physical and chemical composition of soil parent materials, and

ii. The source of the mineralogic contribution to the soil parent material.

. Lead and arsenic were found to be present in some soil samples in amounts exceeding the higher limits of the levels found in soils and are potentially highly toxic to biological systems and therefore of environmental concern. The analysis showed these elements have concentrations above maximum permitted levels of $0.01 \mathrm{ppm}, 0.01 \mathrm{ppm}$ and $0.003 \mathrm{ppm}$ respectively in water for human consumption and above the threshold of contamination of $15 \mathrm{ppm}$ and 20ppm for As and

A

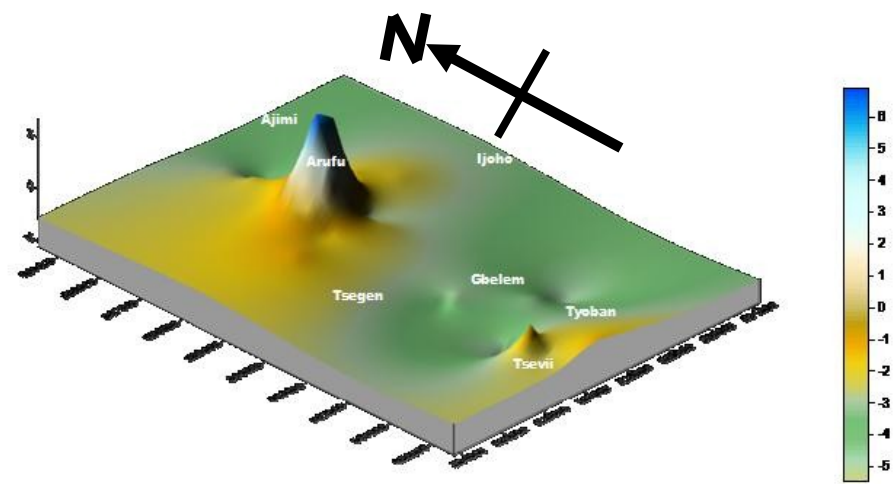

B

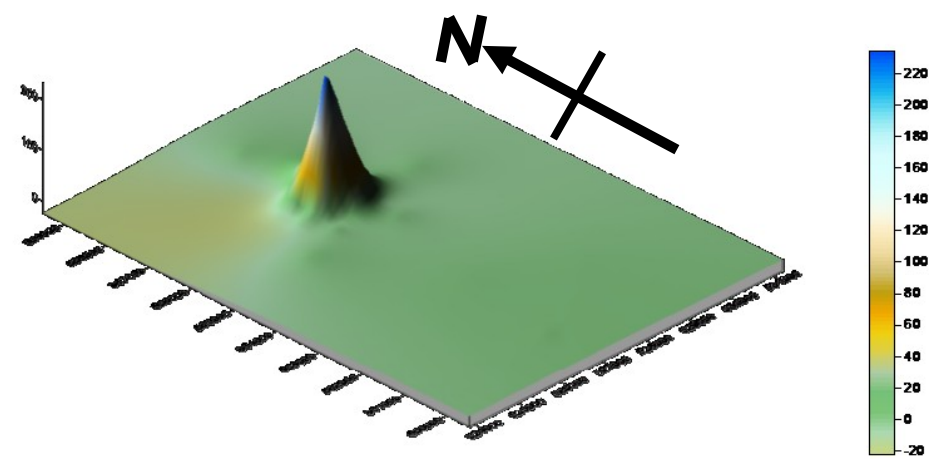

Fig. 14: The Lead contamination map for (a) IGEO and (b) CF values

$\mathrm{Pb}$ respectively. This is buttressed by the values of the Index of Geoaccumulation (Igeo), Contamination Factor (CF) and Degree of Contamination (Cdeg) which indicates moderate to high lead and arsenic contamination of the soils. The most important ores of several base metals such as lead, zinc, and copper are sulphide minerals. The sulphide ore minerals represent the most serious threat of environmental contamination, because they are fairly easily oxidized in the presence of air to considerably more soluble sulphates. As a result, soils, surface and groundwater in the vicinity of the weathering sulphide minerals can be severely contaminated. Although tailings left after exploitation of the minerals are sources of environmental contamination it is the subsequent processing of the ores that results in the greatest environmental problems.

\section{Environmental Impacts and Toxicity}

Mining operations involve excavations that disturb the topography and alter the aesthetics of the area involved. The excavations involve removal of vegetation cover, destruction of wildlife habitats and accelerated erosion. The land is rendered unsuitable for agriculture and the beauty is destroyed. To minimize these effects to the host communities it is important to take some measures such as; 
- Clearing of the vegetation in sequence in order to avoid destruction and generation of large biomass at the same time.

- A watershed management plan has to be developed to compensate for the loss of wildlife habitat.

- Compensation as agreed with the community should be made for lost crops and economic trees. Alternative farming sites should also be made for displaced farmers.

Mining operations leave behind shallow and deep pits. This was observed in parts of the study area where past and ongoing mining operations are concentrated (Plates 4.2a and 4.2b). Some of the pits form a chain extending over several kilometres of land. With repeated rainfall or inflow of water from the streams these pits become death traps for unsuspecting people and animals. This refers to the water that drains from the mines. Lead and zinc are mined as sulphide ores. When sulphur gets oxidized, a by-product of the oxidation process is Tetraoxosulphate VI acid $\left(\mathrm{H}_{2} \mathrm{SO}_{4}\right)$. The resultant runoff from the mines and waste piles (known as acid mine drainage or acid rock drainage) are acidic solutions that can chemically attack other ore minerals and rocks to produce a cocktail of elements that can have a serious environmental impact on receiving rivers and streams. This can reduce biological activity or result in death of living organisms in the area. Noise and vibrations are generated when machines are in operation and during blasting. Stress and shock could result to some residents living in the vicinity. Adequate measures should be taken by mining firms to reduce the direct effect of vibration and noise on the host communities. Such measures include:

- Utilization of latest technology, which guarantee low noise levels. Noise is further attenuated by the use of mufflers and silencers as dampeners. The use of ear defenders should be made mandatory for all workers on site

- Equipment, machinery and tools are serviced regularly to ensure low noise emission.

Airborne particles result from blasting, excavation, transportation and wind erosion of loose fine material. Excessive silica dust results in a lung disease called silicosis. Particles of lead and zinc are also uplifted and easily transported into the immediate environment thereby increasing the levels of contamination.

There were indications of outliers in the data thus it was normalized by log transformation to make them suitable for statistical analysis (Table 1). Lead and arsenic were found to be present in some soil samples in amounts exceeding the higher limits of the levels found in soils and are potentially highly toxic to biological systems and therefore of environmental concern. The analysis showed these elements have concentrations above maximum permitted levels of $0.01 \mathrm{ppm}, 0.01 \mathrm{ppm}$ and $0.003 \mathrm{ppm}$ respectively in water for human consumption ( Standard Organization of Nigeria, 2007) and above the threshold of contamination of $15 \mathrm{ppm}$ and 20ppm for As and $\mathrm{Pb}$ respectively. This is buttressed by the result of the Index of Geoaccumulation (Igeo), Contamination Factor (CF) and Degree of Contamination (Cdeg) which indicates moderate to high lead and arsenic contamination of the soils. Arsenic and cadmium show significant correlations with lead. The result of the geochemical data showed significant regression of lead on arsenic and cadmium as 0.0000 and 0.0149 values respectively indicating a P-value $<0.05$ and adjusted $\mathrm{R}^{2}$ value of $50 \%$ suggesting that concentrations of arsenic and cadmium in particular are suitable for prediction of the various concentrations of lead across the area.

The most important ores of several base metals such as lead, zinc, and copper are sulphide minerals. The sulphide ore minerals represent the most serious threat of environmental contamination, because they are fairly easily oxidized in the presence of air to considerably more soluble sulphates. As a result, soils, surface and groundwater in the vicinity of the weathering sulphide minerals can be severely contaminated. Although tailings left after exploitation of the minerals are sources of environmental contamination it is the subsequent processing of the ores that results in the greatest environmental problems.

\section{Conclusion}

The distributions and concentrations of arsenic, cadmium and lead in the soil samples identified potential risks associated with lead-zinc mineralization and mining due to enrichment of these elements in the surface soils and continuous exposures of human beings and animals to these risks. The concentrations of arsenic and lead are higher than permissible levels and pose a threat to the health of the communities where mining activities are ongoing or were carried out. The observed significant regression and correlations of lead and arsenic reveals a close association between the elements during the process of mineralization. Lead and arsenic found in the soil samples were found exceeded the amounts given by Standard Organization of Nigeria (SON, 2007) as normal levels found in soils which are potentially and highly toxic to biological systems and therefore of environmental concern. The result obtained showed that these elements $\mathrm{As}, \mathrm{Cd}$ and $\mathrm{Pb}$ have concentrations above maximum permitted levels of $0.01 \mathrm{ppm}, 0.01 \mathrm{ppm}$ and $0.003 \mathrm{ppm}$ respectively in water for human consumption (Standard Organization of Nigeria, 2007) and above the threshold of contamination of $15 \mathrm{ppm}$ and 20ppm for $\mathrm{As}$ and $\mathrm{Pb}$ respectively. This is buttressed by the result of the Index of Geoaccumulation (Igeo), Contamination Factor (CF) and Degree of Contamination (Cdeg) which indicates moderate to high lead and arsenic contamination of the soils, surface and underground waters. 


\section{Acknowledgements}

Thanks are expressed to my supervisor and advices and contributions of Prof. E.C. Ashano, Prof. U.A. Lar, Prof. E.O. Ogezi, Mr. Agada, and Mrs Ifeoma. My gratitude also goes to the management and staff of University of Jos for the enabling environment for learning.

\section{References}

[1]. Adikwu-Brown, M.E. and Ogezi, A.E. (1991): Heavy metal pollution from mining practices: A case study of Zurak, Journal of mining and Geology, 7(2), 205-211.

[2]. Akande, S.O. (1988): Mineralogical, Fluid Inclusion and Genesis of the Arufu and Akwana Pb-Zn-F mineralization, middle Benue Trough, Nigeria. Journal African Earth Sciences, 7, 167-180.

[3]. Akande, S.O. (1989): Mineralogical, Textural and Paragenetic studies of the lead-zinc-copper mineralization, lower Benue Trough and their genetic implications. Journal African Earth Sciences, 9, 23-29.

[4]. Alloway, B.J. (1990): Cadmium; Heavy Metals in Soils. In: B. J. Alloway (ed.). Blackie and Son Ltd.,Bishopbriggs, Glasgow. 100124.

[5]. Benkhelil, J. (1989): The origin and evolution of the Cretaceous Benue Trough (Nigeria). Journal of African Earth Science, 8, 251259.

[6]. CCREM (1995): Canadian Water Quality Guidelines. March 1987.

[7]. Canadian Council of Resource and Environment Ministers. Environment Canada, Ottawa.

[8]. Cratchley and Jones, G.P. (1965): A Review of the Geology of the Cretaceous of the Benue Valley. In Geology of Nigeria. Kogbe, C.A. (ed) $2^{\text {nd }}$ Edition. Rock View (Nig) Ltd., Jos. 368-369.

[9]. Davies, B. E. (1990): Lead. In Heavy Metals in Soils, B. J. Alloway (ed.). Blackie and Son Ltd., Bishopbriggs, Glasgow. 177-196.

[10]. FAO Soils Bulletin 65. (1992): Status of Cadmium, Lead, Cobalt and Selenium in Soils and Plants of Thirty Countries.

[11]. Farrington, J.L. (1952): A preliminary description of the Nigerian Lead-Zinc Field. In Nigeria; It's Petroleum Geology, Resources and Potential, Vol.2, pp. 178-179 (A.J Whiteman, 1982). Graham \& Trotman Ltd, Sterling House, London).

[12]. Kabata-Pendias, A. and Pendias, H. (1992): Trace Elements in Soils and Plants, 2nd ed., CRC Press, Inc., Boca Raton, Florida. pp. 365.

[13]. Lagerwerff, J.V. (1972): Lead, Mercury, and Cadmium as Environmental Contaminants. In Micronutrients in Agriculture, Soil Science Society of America, Inc., Madison, Wisconsin, 596-636.

[14]. Lar, U.A. and Sallau, A.K. (2005): Trace element geochemistry of the Keana brines field, middle Benue trough, Nigeria. Journal of Environmental Geochemistry and Health, 27(4), 331-339.

[15]. McBride, M.B. (1994): Environmental Chemistry of Soils. Oxford University Press, Inc. New York, 326-339.

[16]. Norrish, K. (1975): The Geochemistry and Mineralogy of Trace Elements. In Status of Selected Trace Elements in Agricultural Soils of Southern Manitoba. Canada, Haluschak, P., et.al. 1998. Technical Report, pp 20.

[17]. NRCC. (1978a): Effects of Lead in the Environment - Quantitative Aspects. Associate Committee on Scientific Criteria for Environmental Quality, National Research Council of Canada, Ottawa. NRCC No. 16736. pp 779.

[18]. NRCC. (1978b): Effects of Arsenic in the Canadian Environment. Associate Committee on Scientific Criteria for Environmental Quality, National Research Council of Canada, Ottawa. NRCC No.15391. 349 pp.43

[19]. Ntekim, E.E. (2008): Statistical Analysis of Trace Element Concentrations In Shale-Carbonate Sediments from Northeastern, Nigeria. Global Journal of Geological Sciences, 6(2), 95-104.

[20]. Nwajide, C.S. (1990): Sedimentation and Paleogeography of the Central Benue Trough, Nigeria. In The Benue trough structure and evolution. Ofoegbu C.O. (ed) Vieweg, Braunschweig, 19-38

[21]. Obaje, N.G. (2009): Geology and Mineral Resources of Nigeria. Lecture Notes in Earth Sciences 120, Springer-Verlag Berlin Heidelberg, 57-63

[22]. Obaje, N.G., Attah, D. O., Opeloye, S.A. and Moumouni, A. (2006), Geochemical evaluation of the hydrocarbon prospects of sedimentary basins in Northern Nigeria. Geochemical Journal., 40, 227 - 243.

[23]. Offodile, M.E. (1976): Stratigraphy of the Keana-Awe area of the Middle Benue region of Nigeria. Bull. of Geology Inst. of the Univ. of Uppsala N.S. Vol.7, 37-66.

[24]. Olade, M.A., (1976): The genesis of lead and zinc deposits in Nigeria's Benue (Aulacogen). In Nigeria; Its Petroleum Geology, Resources and Potential, Vol.2, pp. 179 (A.J Whiteman, 1982). Graham \& Trotman Ltd, Sterling House, London).

[25]. Smedley, P.L., and Kinniburgh, D.G. (2002): A Review of the Source, Behaviour and Distribution of Arsenic in Natural Waters. Applied Geochemistry, 17, 517-568.

[26]. Standards Organization of Nigeria (2007): Nigerian Standard for Drinking-water Quality, Standards Organization of Nigeria (SON) NIS 554: 2007, Wuse Zone 7, Abuja, Nigeria.

[27]. Tisdale, S.L. (1985): Soil Fertility and Fertilizers. 4th ed. MacMillan Publishing Co. New York. pp 358-403.

[28]. Tseng, C.H. (1999): Chronic Arsenic Intoxication in Asia: Current Perspectives. J. Intern. Med. Taiwan, 10, $224-229$.

[29]. Ure, A., and Berrow, M. (1982): The Elemental Constituents of Soils. In Environmental Chemistry (H. J. M. Bowen, Ed.), Royal Society of Chemistry, London, 94-203.

[30]. Weinstein, P. (1997): The Mount Ruapehu Eruption, 1996: A Review of Potential Health Effects, Australia. New Zealand Journal of Public Health, 21(7), 773-778.

[31]. Webster, J.G. (1999): Arsenic. In Encyclopaedia of Geochemistry (C. P. Marshall and R. W. Fairbridge, Eds.), Chapman and Hall, London, 21-22.

[32]. Whiteman, A. (1982): Nigeria: Its Petroleum Geology Resources and Potentials. Vols. 1 and 2 Graham and Trotman, London, pp. 349 .

[33]. World Health Organization (WHO) Standards (2011): Guidelines for Drinking-water Quality, 4th Edition. WHO Press, 20 Avenue Appia, 1211 Geneva 27, Switzerland.

[34]. Wright, J.B. (1968): South Atlantic Continental Drift and Benue Trough. Tectonophysics, 301-310 